\title{
Building resilient cities: designing resilience in a performative way. The 100RC program.
}

\section{Construire les villes résilientes. Le programme 100RC ou la fabrique performative de la résilience.}

\author{
Lauriane Sabatier ${ }^{1}$, Magali Reghezza-Zitt ${ }^{2}$ \\ ${ }^{1}$ Physical Geography Laboratory (UMR 8592), Panthéon Sorbonne University, Veolia Company, France, \\ sabatier.lauriane@gmail.com \\ ${ }^{2}$ École normale supérieure (ENS) - Paris sciences lettres (PSL), Physical Geography Laboratory (UMR 8592), France, \\ magali.reghezza@ens.fr
}

\begin{abstract}
Resilience is a highly controversial scientific concept that has been widely disseminated in international policies and frameworks. However, operationalizing resilience remains problematic. This paper aims to understand how local actors, in this case cities, implement the resilience imperative. We analyze 82 resilience strategies produced by the cities that have joined the 100 Resilient Cities network, supported by the Rockefeller Foundation. We show that, on the one hand, resilience is not a given baseline that guides urban policies, but a local construction adapted to the specificities and characteristics of each city. Resilience is place-based designed in a performative way, as local actors grasp it and give it content. On the other hand, rather than specific objectives, we argue that resilience provides a method for both recognizing vulnerability and transforming security governance, thereby changing the risk and threat management regime.

RÉSUMÉ. La résilience est un concept scientifique très discuté qui s'est largement diffusé dans les politiques et les cadres d'action internationaux. Pourtant, son opérationnalisation pose problème. Cet article propose de comprendre comment des acteurs locaux, en l'occurrence les villes, mettent en œuvre l'impératif de résilience. En nous appuyant sur l'analyse des stratégies de résilience produites par les villes qui ont adhéré au réseau 100 villes résilientes, porté par la Fondation Rockefeller, nous montrons que d'une part, la résilience n'est pas un donné qui guiderait les politiques urbaines, mais une construction locale, qui correspond aux spécificités et aux caractéristiques de chaque ville. La résilience se construit de façon performative, à mesure que les acteurs locaux s'en emparent et lui donnent un contenu. D'autre part, nous affirmons que la résilience fournit moins des objectifs précis qu'une méthode permettant à la fois de reconnaître sa vulnérabilité et de transformer la gouvernance de la sécurité, ce qui change le régime de gestion des risques et des menaces.

KEYWORDS. Resilience, urban resilience, resilient city, 100 resilient cities (100RC), governance, place-based approach. MOTS-CLÉS. Résilience, résilience urbaine, ville résiliente, programme 100 villes résilientes, gouvernance, territorialisation.
\end{abstract}

\section{Introduction}

Resilience was initially a scientific concept used in various fields [BRA 07] [REG 15]. Academic research on resilience provided an abundant theoretical and methodological corpus, even if the concept is still widely discussed and remains problematic [CHA 17].

Resilience can be broadly defined as the ability to cope with, react, adapt and recover from a disturbance, which may be a slow stress or a sudden shock [ALE 13]. The concept is generally applied to systems and is related to complexity theory [CHA 14] [MEE 15]. Researchers underline the nonlinearity of recovery trajectories, the relationships between the system's resilience and that of its components, and highlight the interactions between the different resilience drivers.

In the late 1990's, resilience became a pervasive theme in the discourse of political, institutional and economic stakeholders, locally, nationally and internationally. In the context of environmental concerns, resilience emerged in the field of disaster risk reduction (DRR) and disaster risk management (DRM), moving from a descriptive scientific concept to a normative imperative on the international 
political agenda [FOL 06] [WEI 15]. Resilience is currently widely used in the field of climate change, providing a baseline to inform mitigation strategies and adaptation frameworks [FIS 16].

Interest in the theoretical concept of resilience raises the issue of its applicability. The operationalization of resilience is particularly difficult in the case of cities. Cities are identified as major contributors to climate change. They are considered as key actors in the implementation of climate action and sustainable development objectives [TOU 12]. Building resilient cities is becoming a new target on political agendas as cities are progressively adopting resilience strategies or integrating resilience into various programs and urban planning. For example, the UN Hyogo Framework for Action is entitled "Building the Resilience of Nations and Communities to Disasters," the World Bank has a "City Resilience Program," and the OECD has provided policy recommendation reports for its "Resilient Cities" program [JON 19].

This paper therefore aims to explore how resilience is understood and implented by cities. We intend to demonstrate that resilience is not something given, but that it is political and locally built. Resilience frameworks do not provide unchallenged and easily operational objectives, but rather an opportunity and a method for integrating and linking the major urban issues, which are specific to each place.

We then seek to consider two hypotheses. First, cities develop their own definition of resilience according to their needs and their specificities. This means that defining resilience is performative: implementating resilience gives content to the concept. Secondly, resilience essentially functions as a methodological tool for designing an integrative urban project, which goes far beyond than the capacity to cope with shocks or slow stresses. Thinking in terms of resilience transform security governance and change the risk and threat management regime.

For this, we studied the "100 Resilient Cities" program, created by the Rockefeller Foundation. The Rockefeller Foundation launched this network in 2013 on the occasion of its centennial. The programm aims to help cities around the world to become more resilient to the physical, social and economic challenges of the 21 st century. The 100 selected cities received advice and financial support to design a resilience strategy. The network of 100RCs ended in July 2019 [BLI 19].

\section{From Urban Resilience to the resilient city}

\subsection{Urban Resilience}

Resilience studies cover a very broad spectrum, with numerous scientific publications. Researchers have shown the exponential increase of works applying the concept to cities since the mid-2000s [MEE 19]. After the attacks of September 11, 2001 and Hurricane Katrina, "resilience" has been used to address cities recovery after disasters [VAL 05] [CAM 06]. The concept has been extended to contemporary events, but also historical and even protohistorical cases. Others works has linked urban resilience, urban sustainability and climate change adaptation [COA 08] [DAV 14].

Several studies have sought to define urban resilience, highlighting the diversity of the academic use and the ambiguities of the term [COA 15] [MEE 16] [BUR 19]. A distinction can be made between works that examine outcomes which occur after the disturbance, and those that deal with outputs observed before [WIN 14]. In addition, authors insist on the political use of resilience in urban contexts. Resilience generally provides narratives that are not ideologically neutral [VAL 05] [MCG 16]. They define then resilience as a discursive, usually normative construct that legitimizes power and can be used to establish or maintain exclusion and domination [RUF 15].

Numerous works on urban resilience consider cities as "networked complex systems" [GOL 03]. They highlight the resilience pathways' diversity. For instance, J. Hernandez has shown that "the resilience" of New Orleans, highlighted by national and local authorities, is not homogeneous at the 
city scale. Reconstruction rates vary considerably from one neighborhood to another. Moreover, resilience trajectories are very different according to the urban system components and the time scale considered [HER 10]. Archaeological works have also highlighted that applying resilience to cities (or to one of their components) over a long period can be problematic [DJA 12] [NOI 13] [ROB 20].

More generally, talking about "urban resilience" issues what is meant by "city". J. Hernandez distinguished between the recovery of the "urbs", i.e. the material dimensions of the city (buildings, networks), and that of "civitas", i.e. it's socio-political dimensions (inhabitants' practices, sociability networks, identity, etc.) (ibid). Using a geohistorical approach, G. Djament provided a diachronic study of Roman centrality and demonstrated how the resilience of the city's functioning is dissociated from that of its identity [DJA 05]. She suggested therefore that "spatial reproduction", inspired by the work of H. Lefèbvre [LEF 91], should be preferred to resilience.

Works have also focused on the city physical components, particularly critical networks and buildings [LHO 13]. They addressed the "build back better" imperative and stressed the importance of planning, urbanism and architecture [FRA 18]. Some insisted on the commemorative dimension of recovery processes, through the so-called "risk culture" or the conservation of traumatic ruins for preventive purposes [LEB 06]. They also examined the conflicts surrounding material reconstruction and highlighted the obstacles to preventive reconstruction.

While works focus on processes, others examine outcomes and understand resilience as a state. Many scholars have issued the so-called "good resilience", highligting the subjective interpretation in ex-post analysis and showing the difficulty of establish objective indicators. They also have strongly criticized discourses that idealize resilience [RUF 15]. Beyond the radiant narrative of a resilience that would allow cities to transform themselves in a better, fairer and more sustainable way, post-disaster feedbacks shown that resilience often consists in a deterioration of initial conditions, poor adaptation and vulnerability increase [DOR 20].

\subsection{The resilient city}

Examining how cities recover from disasters has helped characterize urban resilience. Academic works have provided a broad but non-consensual interpretative framework, which is problematic for the operationalization of the concept [PEL 03, PEL 13].

Resilience implementation is based on the assumption that resilience can be built, strengthened or improved [DES 13] [ELM 14]. Similarly, system responses to disruptions can be anticipated, planned and integrated into strategies [REG 19]. Resilience "operates in two distinct modes: proactive/preventive resilience and reactive/restorative resilience" [VAL 14]. These two modes do not always coincide.

In addition, two complementary interpretations of resilience underpin its design: intrinsic resilience, based on the characteristics of individuals or communities which pre-exist the triggering events; adaptive resilience, based on the reorganization processes which occur after a disturbance [CUT 16]. Interpretations of resilience then oscillate between two poles: approaches that emphasize the role of structures; approaches that stress agency.

The resilience of any system is determined by its adaptive capacity, which may be inherent, given the nature or structure of the system, but which may also be acquired and encouraged or promoted [BRO 11] [THE 21]. If the resilience drivers can be identified for a given system, it should be possible to create or develop them for other systems, either because they are similar or because they face similar disturbances. Recognition of this premise leads to shifting from ex post assessment of one system resilience to the ex ante design of resilient systems [MEE 19]. 
Applied to cities, this hypothesis suggests that resilience properties of urban systems can be created and/or improved ex ante [LU 13]. The focus then moves from urban resilience to the resilient city, i.e. a city "that has the ability to absorb, recover and prepare for future shocks (economic, environmental, social \& institutional)" (OECD). Practitioners therefore seek to understand how cities can increase their resilience. On the one hand they seek to identify resilience drivers and, on the other hand, to develop indicators to measure resilience capacity (and thus the effectiveness of strategies and actions implemented).

In conclusion, the term "resilient city" reflects the shift from understanding resilience to actively building resilience. As such, the "resilient city" leads to the same issues as those raised by resilience itself: The confusion between inherent property, process and outcome; the promotion of resilience as a strategy to respond to any disruption at any time and in any place; the increasingly normative interpretation of resilience; ant the growing emphasis on the measurement and evaluation of resilience [MOS 19].

\section{Case study: The Rockefeller Program "100 Resilient Cities" (100 RC)}

\subsection{What is the "100 RC" network?}

The Rockefeller Foundation is a private charitable foundation that was established in 1913 in New York City by oil giant John D. Rockefeller. In 2013, the Rockefeller Foundation launched the 100 Resilient Cities Network (100RC). The 100RC network was based in New York City and chaired by Michael Berkowitz, formerly Global Head of Risk Management at Deutsch Bank. The 100RC team consisted of 87 professionals, 52 of whom were based in New York and the rest in strategic locations in other cities around the world (London, Singapore and Mexico City).

Cities were selected through a three-phase call for applications from 2013 to 2016. The 100RC network started with a first group of 31 cities selected in December 2013. Eight regions were distinguished: Sub-Saharan Africa, North Africa and the Middle East, Asia, Central America and the Caribbean, Europe, North America, South America and Oceania. Then, one year later, the 100RC network selected another 31 applicants and finally, the last group of cities was chosen in May 2016 to finally reach the number of 97 cities.

The earlier cities joined the network, the more time they had to write their strategies. $94 \%$ of the cities that joined the network in 2013 published their resilience strategies before the end of the $100 \mathrm{RC}$ program. This figure rises to $97 \%$ if we count the cities that have published their strategies since July 2019. 74\% of cities that joined the network in 2014 published their strategies $(83 \%$ counting cities that published after the official end of the 100RCs). Only 54\% of cities that joined the network in 2016 had time to publish their strategy - the latter figure has increased to $77 \%$ since the end of the network. Since the end of the 100RC program, 12 cities published their strategy, making a total of 82 cities out of the 97 .

Advice and financial assistance was provided by the Rockefeller Foundation to the selected cities. They received two-year grants to create a new Chief Resilient Officer (CRO) position within their city government The CRO was responsible for leading the city's resilience efforts and being a direct advisor to the highest city official. By the end of the two years, cities were required to have published their strategies. To do this, the 100RC network provided expertise and support, giving them access to solutions, service providers, private, public and NGO partners who could help them. Finally, the 100RC program aimed not only to help cities to become more resilient, but also to facilitate a global practice of resilience among governments, NGOs, the private sector and individual citizens.

Despite its success, the 100RC network ended in July 2019. The official reason given was the desire to transform the network into an Office of Resilience that would focus on U.S. cities. Following the 
termination of the 100RC network, three entities were created to take over. First, the Global Resilient Cities Network (GRCN) is an organization led by the former 100RC member cities and sponsored by Rockefeller Philanthropy Advisors. It helps cities implement actions, giving priority to those that promote the resilience of the most vulnerable individuals and communities. Cities no longer receive funding and participate in this network on a voluntary basis. Ten new cities are expected to join the network in the near future. Next, members of the 100RC management team created a non-profit association, Resilient Cities Catalyst (RCC), supported from the outset by the Conrad N. Hilton Foundation and Facebook. This organization aims to help cities implement strategies and actions to strengthen their resilience. It operates on the same model as the 100RCs, providing advice and workshops. Finally, the Adrienne Arscht-Rockefeller Foundation has taken up the subject by creating a Resilience Centre to "provide a billion people with resilience solutions to climate change, migration and security by $2030 "$. These three entities are too recent to assess their impacts. This is why we will focus on the results of the study of city resilience strategies within the framework of the 100RC.

The results of the $100 \mathrm{RCs}$ are beginning to be documented in a vast scientific literature. Numerous works study the implementation of the strategies and their real impact, in a monographic perspective [FAI 18] [FIT 19] [FAS 19] [CRO 20] [ROB 20]. Rather, we chose to adopt a comparative approach, to show how cities have appropriated and adapted the Rockefeller resilience framework.

\subsection{The Rockefeller "City Resilience Framework" (CRF)}

In the early 2000s, the Rockefeller Foundation and ARUP (officially Arup Group Limited) a British multinational professional services company headquartered in London, established a partnership. ARUP developed the Urban Resilience Index (CRI) (Figure 1). According to ARUP,

"The City Resilience Index is based on three years of research contributions, case studies and pilot schemes conducted in diverse cities across the world. (...) Our research tells us that universally there are 12 goals that each and every city should strive towards in order to achieve resilience. These are what matters most when a city faces chronic problems or sudden catastrophe".

The CIR is finally structured around 4 dimensions, 7 qualities, 12 objectives and 52 indicators which are considered by ARUP as essential for the resilience of cities. The index is therefore based on the assumption that it is possible to identify universal factors of resilience. 


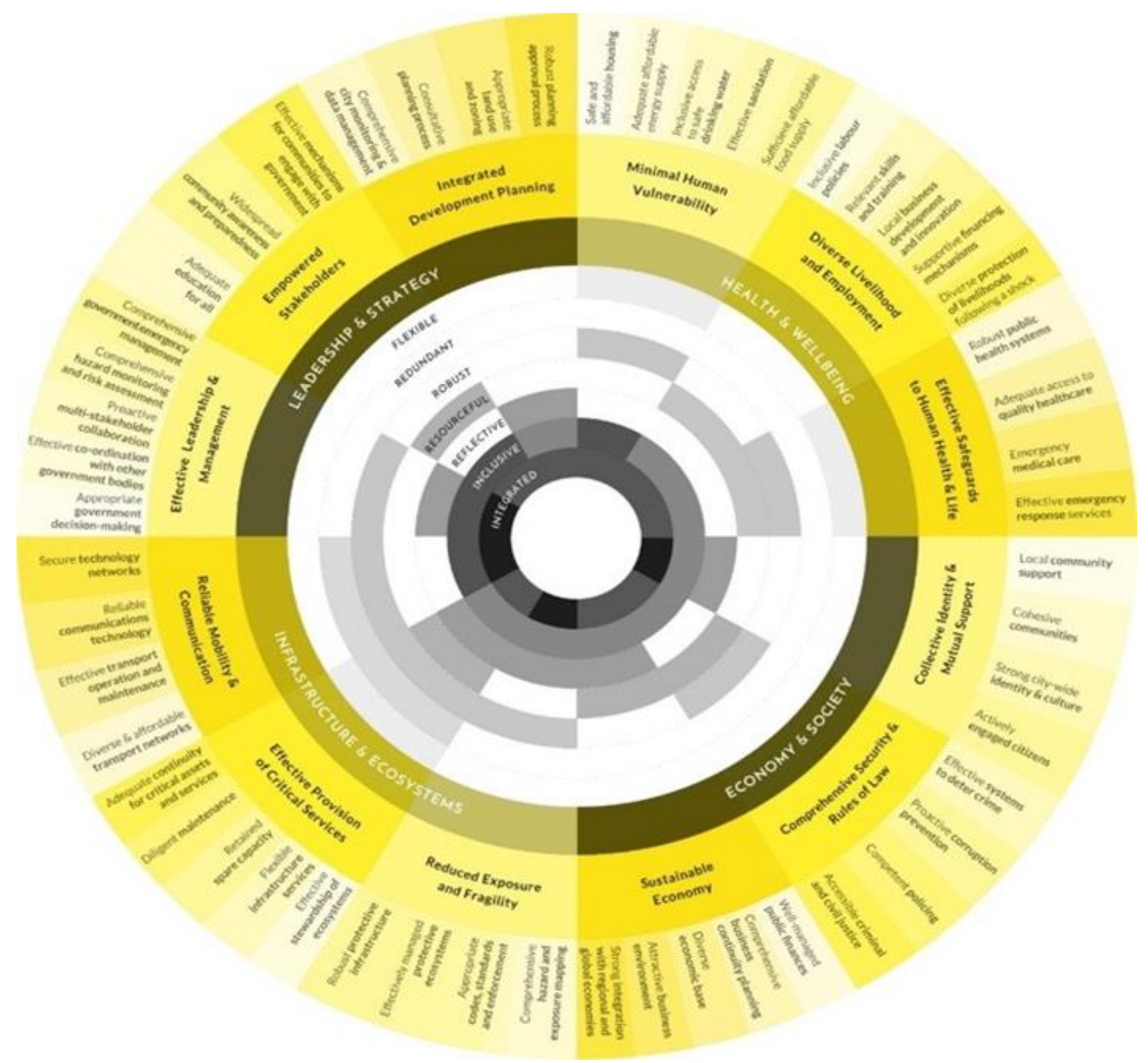

Figure 1. The City Resilience Index (Source: The Rockefeller Foundation and Arup)

The collaboration between the Rockefeller Foundation and ARUP has resulted in the City Resilience Framework (CRF) [ARU 14], directly from the CIR. The CRF aimed to provide cities a simple and operational tool to understand, analyze and self-assess their resilience. The CRF highlights the strengths and weaknesses of the urban system: it shapes the preliminary assessment of the city's resilience and the listing of vulnerabilities that emerge.

The CRF is divided into four categories (inner ring), twelve drivers (second ring). The four categories are considered as basic features existing more or less in all local systems. The twelve drivers are seen as basic indicators to explore the city's ability to cope with shocks and stress. They describe the basic attributes of a resilient city. The Framework is designed for multiple risks. The Rockefeller Foundation and ARUP's approach is based on a cross-cutting and holistic understanding of resilience [SPA 17]. 


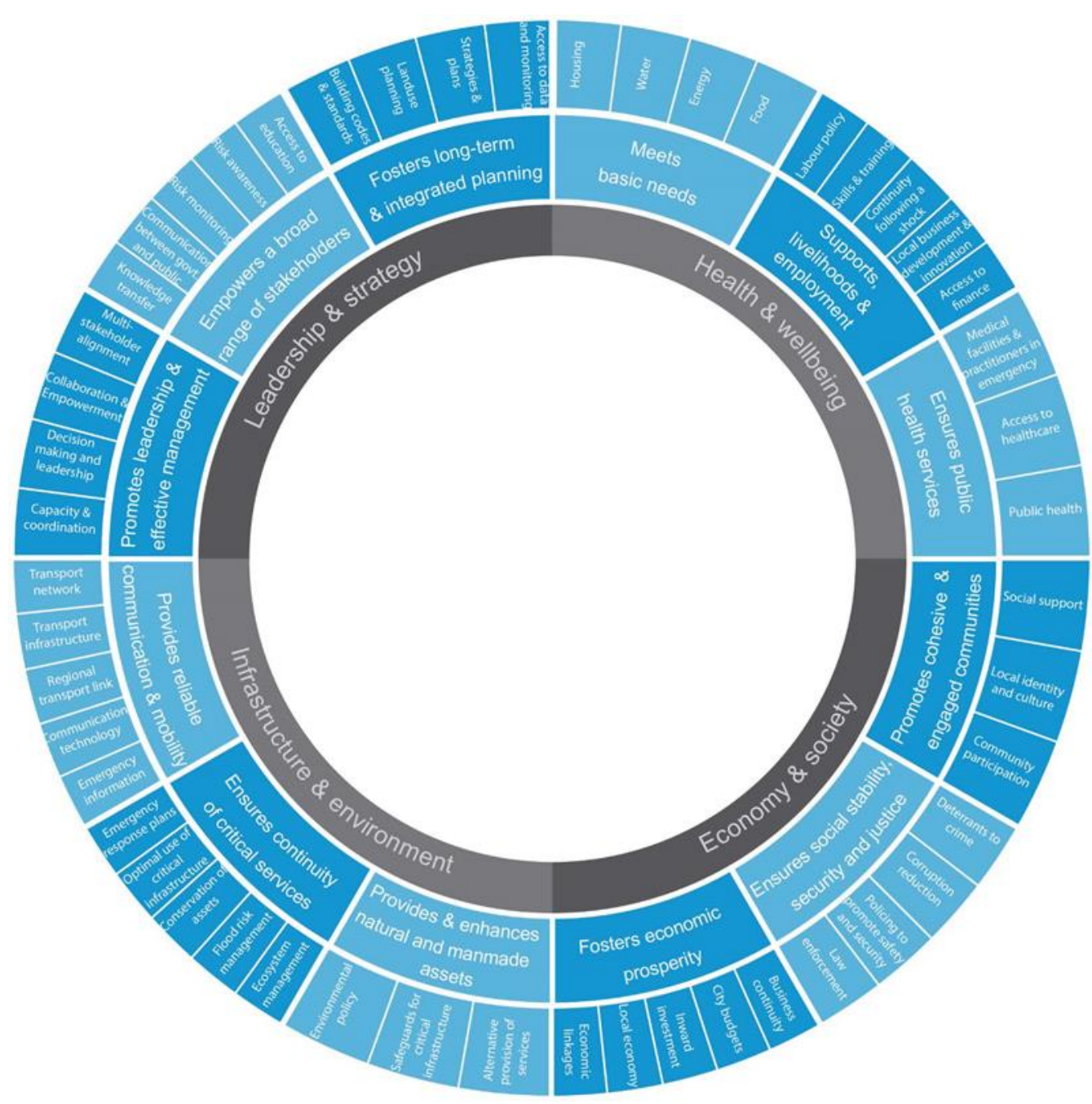

Figure 2. The City Resilience Framework (Source: The Rockefeller Foundation and Arup)

Resilience strategies are designed in several stages. Firstly, each city collects territorial data through consultation between the CRO and local stakeholders, in order to identify its vulnerabilities. Results are presented through a Resilience Wheel. Several tools were proposed by the Rockefeller Foundation to the CROs, to help them design their resilience strategy.

The CRF was the main and most comprehensive one. Other analytical tools were also provided to guide CROs, such as the City Resilience Actions Inventory, to document and analyse existing plans, policies and projects in the city; the City Resilience Perceptions Assessment, to grasp local stakeholders' perceptions of the city's resilience; the City Resilience Assets \& Risks Tool, to identify the main shocks and stresses that a city faces and their impacts; the Field of Opportunity, to bring together the hundreds of actions designed by cities and focus on those that would have the greatest impact on resilience.

We conducted a survey among the CROs in order to grasp how the CROs use these tools. 16 CROs, who were in charge when their city's resilience strategy was being developed, responded to our survey (20\%). They were from Ramallah, Paris, The Hague, Salvador, Rotterdam, Quito, Buenos Aires, Boulder, Panama, Wellington, Dakar, Glasgow, Durban, Semarang, Chennai and Santiago de los Caballeros. The panel of CROs that responded to the survey is fairly broad and representative, although we note an under-representation of North American cities and a slight over-representation of cities that entered Round 1. 
The survey show that all used at least one tool provided by 100RCs. Of the 16 CROs who responded, 13 used the CRF (81\%), 9 the City Resilience Perceptions Assessment (56\%), 8 the City Resilience Actions Inventory (50\%) and the City Resilience Assets \& Risks Tool and 6 the Field of Opportunity (36\%). The majority of the 16 CROs reported feeling "moderately to very guided by 100RCs". However, the CROs were given enough freedom to take full ownership of the resilience concept and its implementation. Indeed, 12 responding CROs (75\%) reported that they had developed their own tools and organised as many workshops as they wanted (from a few workshops to fifty or more).

From which city are you or were you the Chief Officer Resilience? How has your position as Chief Officer Resilience evolved since the end of the 100RC network?

Did you know about urban resilience before the Rockefeller Foundation tender?

Approximately, how many workshops were required to develop your resilience strategy?

Have you used the tools provided by 100RC? If yes, which ones? Have you developed your own tools?

On a scale of 1 to 5 , would you say that you were very guided and directed by the 100RC process or, on the contrary, very free in the development of your strategy? (1: very guided and 5: very free)

Have you modified/adapted your resilience strategy since its publication? If so, what did you change and why?

How is the resilience strategy different (or not) from other frameworks for actions in your city?

Finally, since the end of the 100RC network in the summer of 2019, has your city continued to make progress in urban resilience? If so, how and with which partners (Resilient Cities Network, other)?

Figure 3. Extract from the CROs survey questionnaire

After this first step, cities define the policies needed to reduce their vulnerabilities. Further workshops were held to identify actions that must be implemented to fill the gaps and thus move towards greater resilience. With this data, cities can produce their own strategy, which is finally drafted, adopted and implemented. It can be adjusted over time in an iterative way. Indeed, already almost a third of the CRO (5) who responded to our survey reported that they have already adapted it.

\section{Materials and method}

We chose to compare the cities of the 100RC network. We began by building a database based on the profile of each city, using a set of indicators: world region, surface area, number of inhabitants, density, hemisphere, altitude, status (capital of country, region, etc.), GDP per capita and human development index. We have added location (island, maritime or lake coast, river), insofar as it can be associated with specific hazards (sea level rise, coastal erosion, floods, storms, etc.). Finally, we have included in the database the time at which the city joined the network and the status of the strategy's development (see table 1). At the same time, we reviewed the grey literature on the 100RC program, such as methodological guides. We also had access to several public speeches by the 100RC director. 


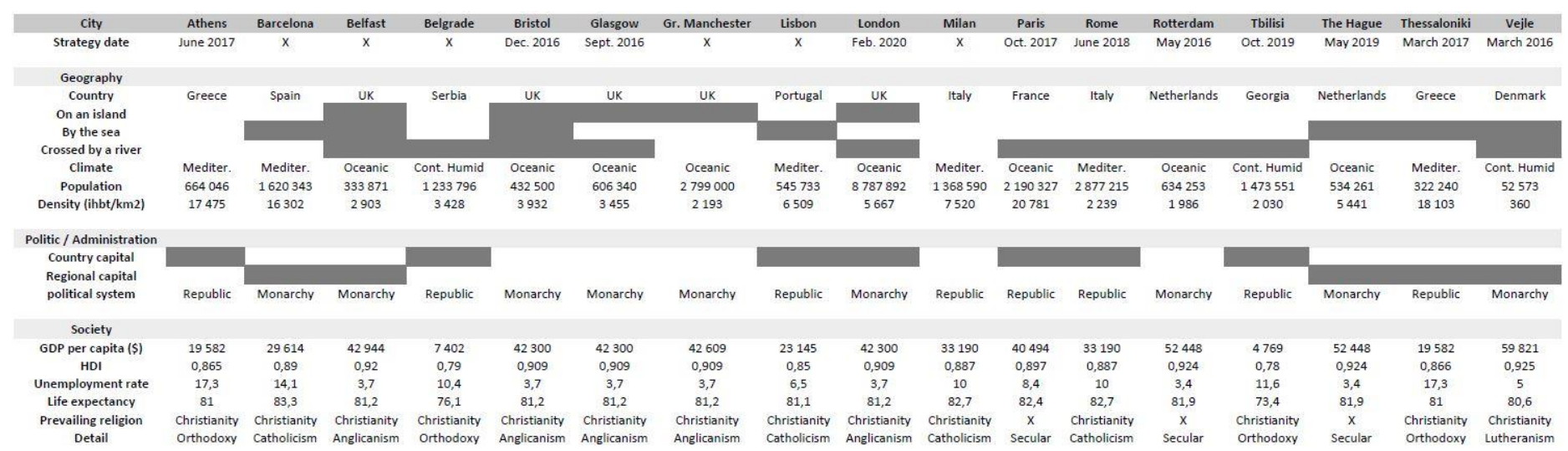

Table 1. Ranking of the criteria of European cities members of the 100RC network (Source L. Sabatier).

We then empirically analyzed the 82 strategies published during the study. We worked on the English versions. These strategies have almost all the same writing plan. They always begin with 3 letters (one from the mayor of the city, one from M. Berkowitz, president of the 100RC and one from the $\mathrm{CRO}$ ), followed by a focus on the $100 \mathrm{RC}$ network, an explanation of the CRF and a presentation of the history of the city and the shocks it has suffered in the past. A timeline explains how the strategy was built. The main characteristics of the city (population, unemployment rate, economic growth rate, poverty rate, economic context, types of activities, biophysical properties, crime rate, health indicators, etc.) are then described, with significant variations between cities. Finally, each strategy includes a "vision" and/or "challenges" section (what each city wants to achieve), defines "goals", resulting from the analysis of vulnerabilities, and proposes several "actions", which are extremely diverse depending on the city. All strategies also present a list of stresses and shocks that they must face. This list appears most of the time between the general description and the description of goals and actions.

We started from the "vision/challenge" part and the list of shocks and stresses as a basis for our analysis. We extracted the vulnerabilities identified by the cities. These vulnerabilities do not necessarily appear in the form of keywords. We therefore had to read the strategies, identify the different vulnerabilities and then group them together under common labels and sub-labels (Figures 4 $\& 5)$.

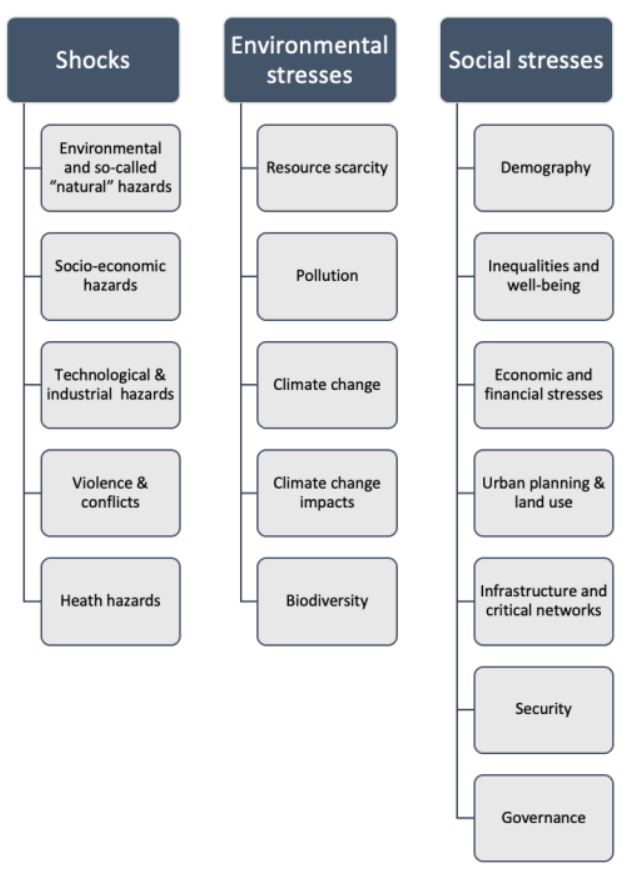

Figure 4. Identification of labels and sub-labels encompassing different types of threats and/or vulnerabilities 


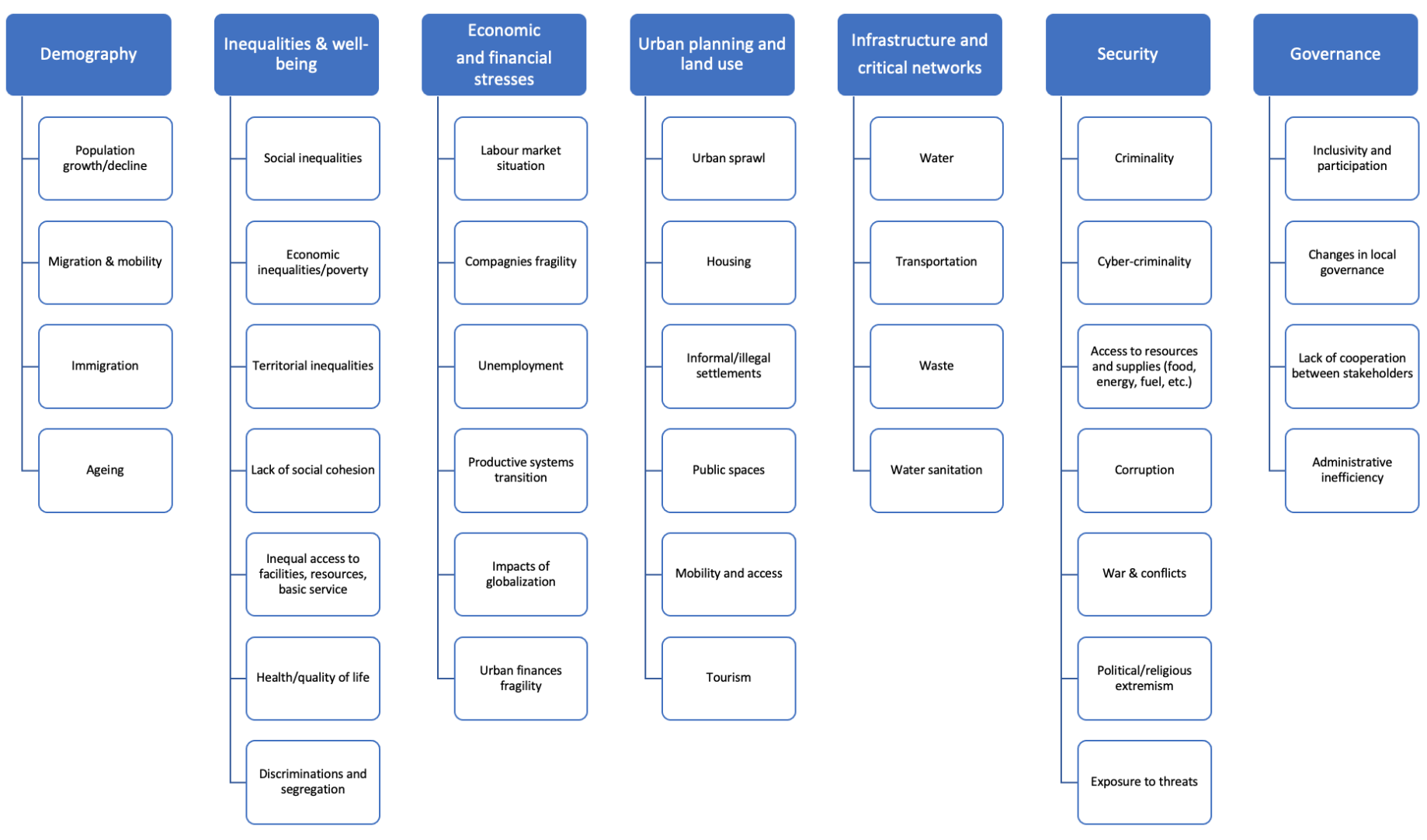

Figure 5. Identification of sub-labels in "social stresses"

We then created a second database that indicates the priority targets for each city with regard to the identified vulnerabilities. (see table 2 for example).

We crossed the characteristics of the cities grouped in the first database with the vulnerabilities listed in the second to see whether certain factors (location, geographical proximity to a river or coast, belonging to a developed or developing country, economic indicators - poverty, GDP per capita, unemployment rate -, city density, age) had a significant impact in the definition of priority objectives

Finally, we seek to better understand how the cities in the $100 \mathrm{RC}$ network analyze their fragility and direct their efforts to become more resilient.

\subsection{The panel of the cities belonging to the 100RC}

82 cities have already produced their strategies, and these cities are unevenly distributed around the world. Some regions are over-represented. Cities in North America, Europe and Asia are more numerous than others, although all regions of the world are represented. According to the division established by the Rockefeller Foundation, 33 cities are located in North America (including 25 in the United States), 17 are Asian, 17 are European, 9 are in South America, 3 are in Central America and the Caribbean, 9 are in Sub-Saharan Africa, 5 are in the Middle East and North Africa, and 4 are in Oceania.

59 cities in the network $(60.8 \%)$ belong to countries with a per capita GDP above the world average (US\$11,428 current in 2019 according to the World Bank). 62 cities (63.9\%) have an unemployment rate below the world average. 25 cities of the 100RC (25.8\%) are located in emerging countries, reflecting their integration into globalisation and Rockefeller's strategy. 84\% of them have published their strategy. 


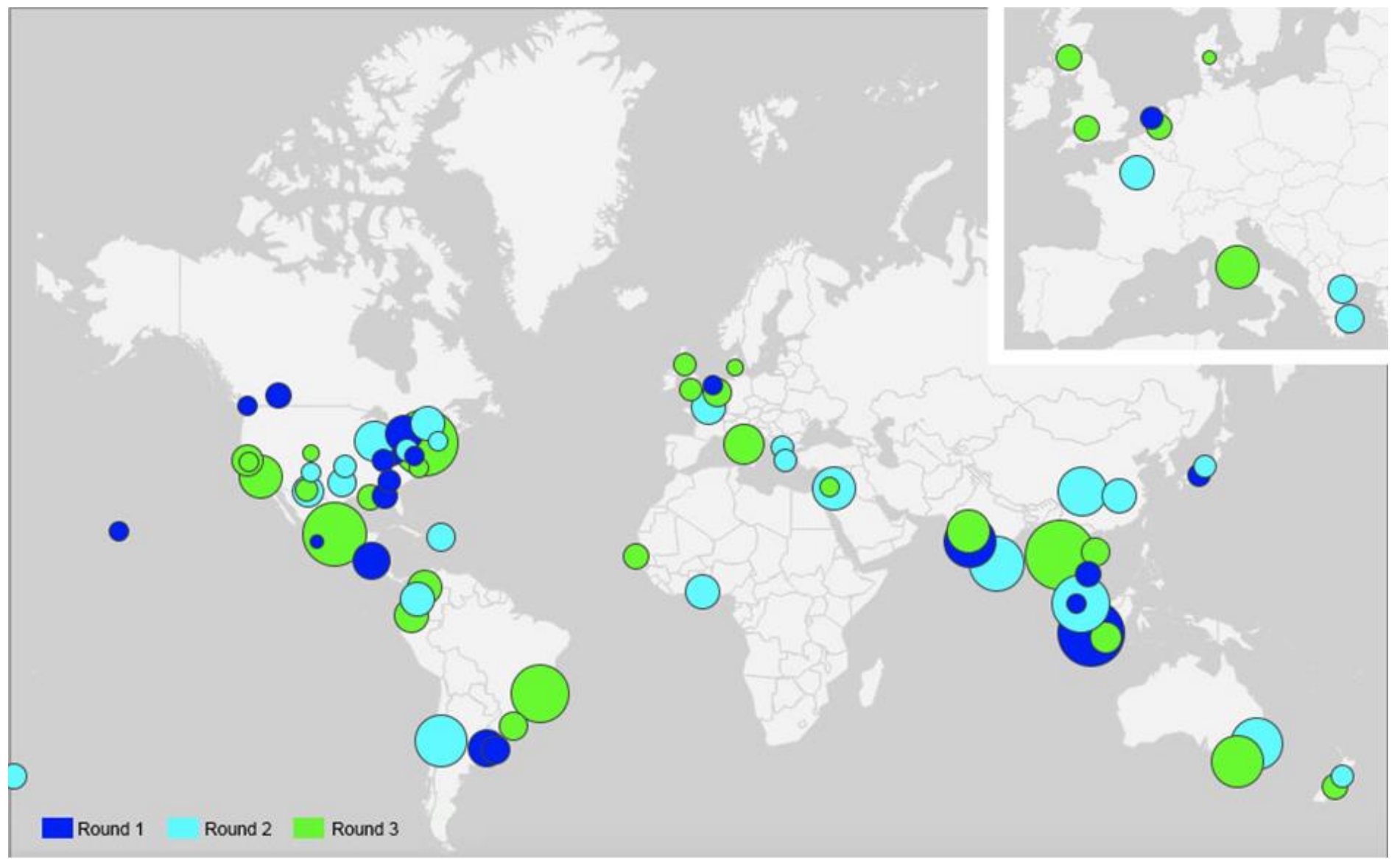

Figure 6. Cities of the $100 R C$ network which have published their strategy according to their entry into the network

The most populated city is Lagos in Nigeria with 20,000,000 inhabitants and the least populated is Ramallah in Palestine with a little over 45,000 inhabitants. However, more than $70 \%$ of the cities have more than 500,000 inhabitants. $77 \%$ of the cities in the network are located in the immediate vicinity of water (ocean, sea, large river, lake, etc.). There are as many capitals (or chief towns) as there are other cities.

\section{Results}

\subsection{At the global level}

\subsubsection{The orientations of the strategies vary significantly across the world's regions}

The comparison shows significant differences between regions of the world. We started from the division made by the Rockefeller Foundation between 8 regions, but we have grouped together Central and South America. For the Middle East/North Africa and Oceania, the number of published strategies is too small to be studied in isolation. In this study, we will focus on the vulnerabilities cited by at least a third of the cities.

All strategies clearly separate shocks from stresses. $85 \%$ of the 82 cities mention their vulnerability to hydro-climatic hazards (floods, storms, rain). Mobility problems are cited by $51 \%$ of the cities. This is followed by socioeconomic inequalities $(47 \%)$ and infrastructure problems (failure/insufficiency/ageing) (46\%). Poverty and impoverishment of the population are cited by $40 \%$ of the cities. Finally, only $39 \%$ of the strategies explicitly mention climate change.

These vulnerabilities are cited as priority targets by all regions of the world. However, very specific issues appear. For example, 50\% of North American cities (where the United States is largely over- 
represented) considered that fighting againts racism and racial discriminations is one of their priority targets to improve resilience. North American cities also cite a lack of affordable housing at $40 \%$. The priorities that stand out in Europe alone are poor air quality, cited by 6 of the 11 cities (54\%), terrorism, immigration and governance issues, cited by 4 cities each (36\%). In Latin America (South America, Central America and the Caribbean), specific priorities are violence, crime and insecurity, cited by 8 out of 12 cities (66\%) and lack of education, cited by 4 cities each (33\%). In Sub-Saharan Africa, two specific issues stand out: Demographic pressure, linked to rapid population growth, and the absence or failure of sanitation networks, each cited by 3 cities out of 6 that have published their strategy $(50 \%)$. Finally, Asia is the only region in the world that has made environmental pollution a priority, cited by 5 out of 15 cities (33\%).

Other priority targets are cited regularly: so-called "natural hazards" such as drought, heat waves, earthquakes and landslides; epidemics; unemployment; deteriorating economic conditions.

Nevertheless, at least 3 out of 4 cities in Oceania cited hydro-climatic hazards and heat waves, and socio-economic inequalities. 3 out of 4 cities in North Africa and the Middle East cited problems related to transportation, mobility and loss of cultural identity, forgotten traditions and customs.

\subsubsection{Priority targets and city types}

Flooding is the first hazard cited in proportion, but it is surprising to note that, while more than half of the cities are located by the sea, only $18 \%$ of them cite rising sea levels as a problem.

Compared to other cities, the 10 least dense cities highlighted pandemic risks, infrastructure failaure, poverty and socio-economic inequalities, unemployment, degraded economic conditions, transportation problems, crime/violence and health problems (see Table 2).

The 10 most dense cities focus on climate change, poor air quality, transportation problems, demographic pressure, poverty and degraded economic conditions, infrastructre failure (see Table 3 ).

Gr. Miami Huangshi Louisville Melbourne New Orleans Panama Santa Fe Sydney Toyama Vejle

Socio-economic inequalities Unemployment

Degraded economic condition Transport or mobility problems Violence/insecurity/crime Health problems

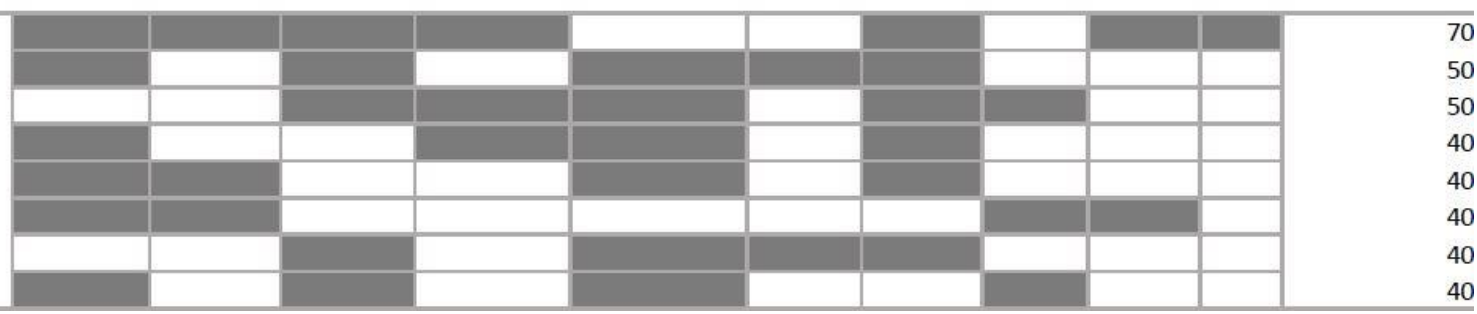

Table 2. Priority issues cited by the 10 least dense cities that have published their resilience strategies (Source: L. Sabatier based on 100RC resilience strategies) 


\section{Stresses}

Environnemental

\section{Climate change}

Poor air quality

\begin{tabular}{|l|l|l|l|l|l|l|l|l|l|}
\hline & & & & & & & & & 60 \\
\hline & & & & & & & & 50 \\
\hline
\end{tabular}

Social

Transport or mobility problems demographic pressure

Poverty

Degraded economic condition

Infrastructure failure

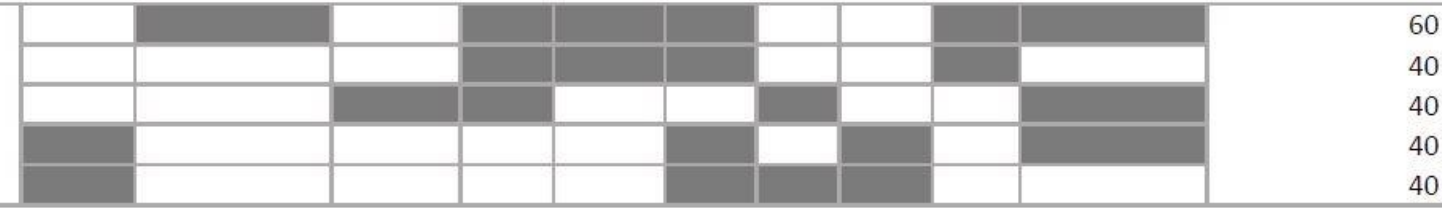

Table 3. Priority issues cited by the 10 densest cities that have published their resilience strategies (Source: $L$. Sabatier based on 100RC resilience strategies)

The 10 cities in the network that belong to countries with the highest HDI highlight the issues of hydro-climatic risks and heat waves, pandemics, terrorism. They also focus on, climate change and socio-economic inequalities, poverty and infrastructure failure (see table 4).

Calgary Melbourne Montréal Rotterdam Singapore Sydney The hague Toronto Vancouver Vejle

Terrorism
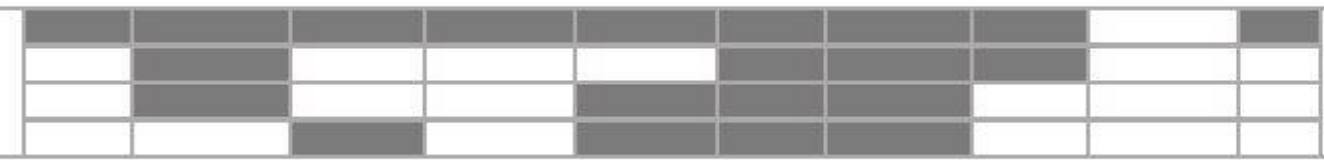

Stresses

Environmental

Climate change

Social

Socio-economic inequalities

Infrastructure failure

Poverty

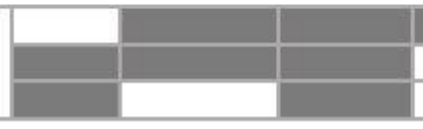

\begin{tabular}{|r|r|r|r|r|r|r|r|}
\hline & & & & & & & 70 \\
\hline & & & & & & \\
\hline
\end{tabular}

Table 4. Priority issues cited by the 10 cities belonging to the countries with the highest HDI (Source: $L$. Sabatier based on 100RC resilience strategies)

The 10 cities belonging to countries with the lowest HDI highlight hydro-climatic hazards, pandemic, transportation problems, water shortage, unemployement, poverty and infrastructure failure (see Table 5). 


\section{Stresses}

\section{Environmental}

\section{Social}

Transport problems unemployment Poverty
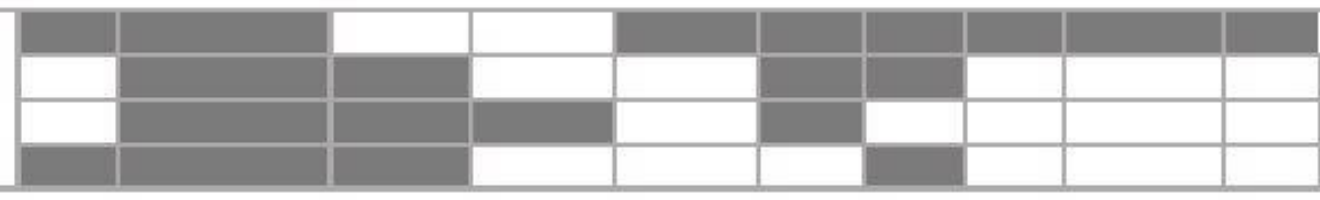

Table 5. Priority issues cited by the 10 cities belonging to the countries with the lowest HDI (Source: $L$. Sabatier based on $100 R C$ resilience strategies)

Cities with a life expectancy above the world average cite heat waves, unlike cities with a life expectancy below the world average. Cities with high unemployment give higher priority to lack of education, violence or crime and poor economic conditions. Only 4 cities (including Paris) cite gender equality as one of their challenges.

The size of the cities (number of inhabitants) does not influence the priority targets, nor does being a capital city. Nevertheless, half of the capitals cite climate change as an issue, compared to only $39 \%$ of the total number of cities.

Focusing on the United States, there are significant differences in city priorities between Democratic and Republican cities. Indeed, while they all focus on socio-economic inequalities, poverty, drought, failing and aging infrastructure and hydro-climatic hazards, Democratic cities focus on climate change, lack of affordable housing, earthquakes and fires, while Republican cities focus on racism, health problems and heat waves.

\subsection{Focus on European cities}

11 European cities have published their strategies: Vejle, Rotterdam, Glasgow, Bristol, Thessaloniki, Athens, Paris, Rome, The Hague, London and Tbilisi. 


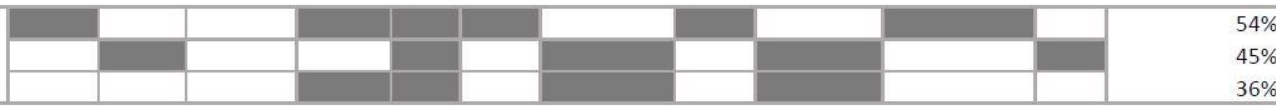

Social

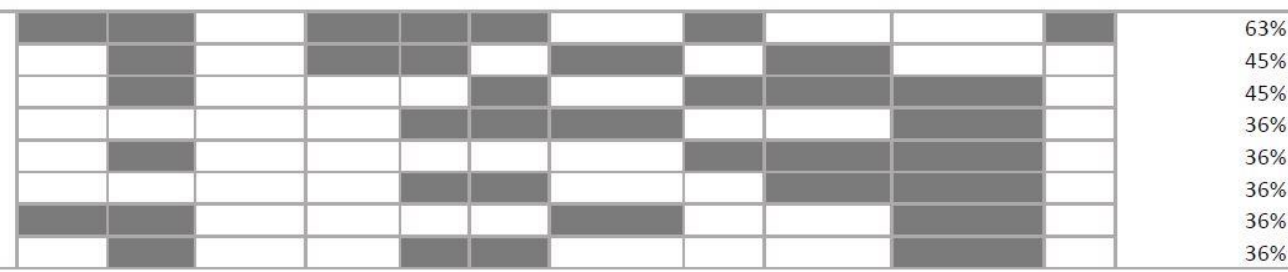

Table 6. Ranking of priority issues/vulnerabilities of European cities that are members of the 100RC network (Source: L. Sabatier based on resilience strategies).

10 of them $(90 \%)$ cited hydro-climatic hazards (Bristol, Rotterdam, The Hague, Vejle, Paris, Athens, Rome, Thessaloniki, London and Tbilisi). 7 cited the failure, insufficiency or ageing of infrastructures and buildings (63\%) (Bristol, Vejle, Paris, Athens, Rome, London, Tbilisi). 6 cited air quality/air pollution (54\%) (Paris, Athens, Rome, Thessaloniki, London, Tbilisi). 5 cited heat waves (45\%) (The Hague, Paris, Athens, Thessaloniki, London), climate change (Bristol, Rotterdam, The Hague, Vejle, Paris), socio-economic inequalities (Bristol, Rotterdam, The Hague, Paris, London) and transport and mobility issues (Bristol, The Hague, Rome, Thessaloniki, Tbilisi). Bristol, Paris, Rome, and Thessaloniki cited governance issues. Lack of social cohesion, aging population, demographic pressure, health inequalities, deteriorating economic conditions, land movements, demonstrations, cyber attacks, urban heat islands, civil unrest, lack of affordable housing, inner city housing decay, crime, food security, and health problems were also cited.

Pandemic risk appears in only three strategies (Bristol, The Hague, London), and only two strategies mention water quality/scarcity (Bristol, Paris). Bristol and Athens cite social, civil and political unrest. Only The Hague mentions racism. Rotterdam highlights the influx of refugees and asylum seekers. Rome emphasizes the loss of biodiversity, but also tourist pressure and mismanagement of the city. Thessaloniki cites snow, lack of green spaces and dependence on European funding. Vejle mentions the vulnerability of employment due to the instability of world markets and urban sprawl. Glasgow cites energy poverty and lack of skilled labor. London cites Brexit as a stress.

\section{Discussion}

\subsection{The 100RC resilience framework: A guideline that is both universal and flexible}

The Rockefeller Foundation has adopted its own definition of resilience to be relevant to cities:

"Resilience is the capacity of individuals, communities, institutions, businesses, and systems within a city to survive, adapt, and grow no matter what kinds of chronic stresses and acute shocks they experience".

The definition of resilience brings together short-term urban resilience (the response of each urban subsystem to various disturbances) and long-term resilience (the overall resilience of the city as part of 
continuous improvement). The 100RC network also refers to the "many challenges of the $21 \mathrm{st}$ century", which is rather vague. Surprisingly, 100RC's definition uses the concepts of adaptation and transformation without mentioning climate change.

100RC also emphasizes the term 'growth': resilience is not simply seen as a curative response to an uncertain future that would constrain cities and hinder their development. It is closely associated with prosperity. This echoes the interpretation of a disaster as an opportunity to improve, create and innovate. The definition therefore refers to adaptive resilience, which promotes emergence and transformation, not a return to the status quo ante. The Foundation's discourse is very explicit. Its approach aims to move beyond 'business as-usual models of reactive planning and siloed decisionmaking' and create the 'strength and flexibility essential for us to thrive in the 21 st century'. They do not want to provide ready-made solutions, but to develop new models of governance.

To justify this position, the Rockefeller Foundation cites the case of Paris. The foundation recalls that the city joined the network in 2014 and that at that time, Paris was highlighting its vulnerability to floods and heat waves. In 2015, Paris was hit by deadly terrorist attacks, which led the city to change its strategy. For the Rockefeller Foundation, this example shows that each city "needs to plan holistically, so that a city is prepared for whatever shocks and stresses may arise". This view of resilience as a generic property equates it with preparedness, rather than with actions actually implemented.

Finally, the definition of the $100 \mathrm{RCs}$ is aimed at individuals as well as collectives, as institutions or companies, which reflects the systemic approach without constraining it. Each city is therefore free to determine the field of action, the actors involved and the components of the urban system included. In order to simplify the resilience policies' implementation and limit itself to administrative issues, 100RC's definition of urban resilience is restricted to the city level. This choice offers each municipality the opportunity to implement its strategy according to its particular governance modes.

\subsection{When implementing the concept gives it content}

The Rockefeller Foundation has chosen to offer a broad understanding of urban resilience, so that the various actors can grasp the notion. In this sense, it has a universal vocation and illustrates the international diffusion of the concept. Although the CRF and the workshops are designed on the same model, which could lead to standardized strategies, cities fully embrace resilience and develop strategies that are very specific to their needs. As such, it is locally anchored.

The priority targets show that sensitivity to risk varies considerably from one city to another. They show that risk is in fact a social construction: hazard and threats only exist when they are perceived as such [SLO 00]. Floods are high on the list because most cities are located in flood-prone areas, either on river banks or on the coast, and floods are a major risk in terms of damage. Other natural hazards reflect the characteristics of the physical environment and the history of cities (e.g. sensitivity to seismic risk). Sensitivity to heat waves in Europe is reminiscent of the traumas of 2003. It can also be assumed that vulnerability to heat events is higher in these cities, due to the higher proportion of elderly people. The relative absence of climate change shows the unequal sensitivity to this issue, even after the Paris agreement. In particular, the issue of sea level rise remains underestimated.

It is interesting to note that the priority objectives vary according to the regions of the world, particularly with regard to social and economic risks. The issue of racism is therefore extremely present in North America, depending on the history of the United States, and is thought to be linked to issues of inclusion and social justice. In Europe, inclusion is treated more in terms of poverty, unemployment and inequalities, again reflecting the history of cities and dominant value systems. Ageing issues are more important here, given the demographic profiles. Latin America cities, which suffer from high crime rates, focus on issues of violence, which are linked to poverty. It can therefore 
be seen that the characteristics of cities (location, density, history, political majority) influence the perception of risks and the definition of priority targets.

Finally, the analysis the different strategies indicates that each city appropriated resilience and interpreted it in its own way, as the design process unfolded. The definition of resilience gives it contents in a performative way. Translating resilience into an operational programme leads to the production of disparate lists of measures, the systemic coherence of which is sometimes difficult to grasp and which seem far from the expected holistic and cross-cutting approach. Nevertheless, each strategy is unique, even if the initial framework is identical. Cities have designed their strategies according to their specific characteristics, needs and risk awareness. The strategies are place-based [CUT 08].

\subsection{Resilience is used as a method more than a fixed agenda for action}

The Rockefeller approach reveals first of all that they consider cities to be major actors in risk and crisis management. The growing importance of cities in the global South clearly indicates a change in their weight in globalization.

The CRF does not specify what resilience is, beyond more general considerations. Hazards, vulnerabilities and resilience factors are often mixed. Some elements (lack of social cohesion, governance issues, poverty, financial issues) are both threats and factors of resilience. However, developing strategies helps each city to identify its vulnerabilities, which means recognizing them.

In its implementation, resilience seems to be less an objective in itself, associated with well-defined operational measures, than an opportunity and a method for strengthening the safety of inhabitants and places. The diversity of actions distributed across the strategies shows that resilience is not necessarily understood as the ability to cope with all shocks, stresses or threats, whether known or unknown. Rather, it is seen as an opportunity for better preparedness. Designing a resilient city is above all an opportunity to restore the agency, even if urban crises are inevitable, even if strong vulnerabilities exist.

The introduction of resilience as a new baseline for urban planning and actions then contributes to the display of risk and the construction of a new narrative, which highlights the capacity to anticipate and respond to threats and uncertainty [VAL 05]. The implementation of resilience provides an opportunity to challenge the urban project, the governance mechanisms, and to engage in dialogue with local actors and municipalities. One can think here of what Solecki and al. [SOL 17] have called "risk management regimes, i.e. an assemblage of policies, strategies, and regulations that collectively define a dominant paradigmatic management approach". Solecki and al. distinguish 4 regimes: collapse, resistance, resilience and transformation. Resilience is the regime in which the system develops flexibility to adapt in response to threats and hazards without changing its configuration. It echoes the notion of "incremental adaptation". In contrast, transformation refers to structural change and "transformational adaptation" [PEL 15].

Rockefeller's approach fits perfectly with the resilience risk management regime that balances the imperatives of adapting to threats, including unknowns, and growth. The objectives are fixed, but the approach is very flexible and targets are negotiated. The CFR is plastic enough to encompass "the fullest possible range of policy options within particular risk and governance contexts" [PAH 07]. The adoption of the resilience regime results from the recognition that ecocomic, demographic and sociopolitical, and now environmental and health pressures are dynamic, and that sustainability planning must be anticipatory. Putting resilience on the agenda helps to maximize the policy space of existing regimes through governance renewal. 


\section{Conclusion}

A study of the strategies adopted by the cities of the $100 \mathrm{RC}$ network shows that there is no single path to the resilient city and that the resilience concept can be interpreted very differently by local actors. The strategies are not replicas of a general framework: they reflect the anchoring of this framework in a specific place. The framework is filled out and adapted by local actors to each context.

Finally, resilience is not a pre-existing and universal guide for urban policies, but a local construction adapted to the specificities and characteristics of each city. Resilience is a local construction functioning in a performative way, as local actors grasp it and give it content. Rather thant giving specific objectives, resilience provides a method for both recognizing vulnerability and transforming security governance, changing the risk and threat management regime

\section{Bibliography}

[ALE 13] ALEXANDER D.E., « Resilience and disaster risk reduction: an etymological journey », Nat. Hazards Earth Syst. Sci., n¹3, p.2707-2716, 2013.

[ARU 14] ARUP, City resilience framework, London: ARUP group ltd, 2014.

[BLI 19] BLISS L., «"100 Resilient Cities" is No More. Now What? » City Lab, April, 2019.

[BRA 07] BRAND F.S., JAX K., «Focusing the meaning(s) of resilience: Resilience as a descriptive concept and a boundary object », Ecology and Society, 12(1):23, 2007.

[BRO 11] BROWN K., WESTAWAY E., «Agency, Capacity, and Resilience to Environmental Change: Lessons from Human Development, Well-Being, and Disasters », Annual Review of Environment and Resources, 36(1), p.321-342, 2011.

[BUR 19] BURAYIDI M.A, ALLEN A., TWIGG J., WAMSLER C. (eds.), The Routledge Handbook of Urban Resilience, Routledge, 2019.

[CAM 06] CAMPANELLA T.J., «Urban resilience and the recovery of New Orleans », Journal of the American Planning Association, 72(2), p.141-146, 2006.

[CHA 14] CHANDLER D., Resilience: The governance of complexity, Routledge, London, 2014.

[CHA 17] CHANDLER D., COAFFEE J. (eds.), The Routledge handbook of international resilience Routledge, Taylor \& Francis Group, London, New-York, 2017.

[COA 08] COAFFEE J., « Risk, resilience, and environmentally sustainable cities », Energy Policy, 36(12), p.4633-4638, 2008.

[COA 15] COAFFEE J., CLARKE J., « On securing the generational challenge of urban resilience », Town Plan Rev, n'86, p.249-255, 2015.

[CRO 20] CROESES S., GREEN C., MORGAN G., «Localizing the Sustainable Development Goals through the Lens of Urban Resilience: Lessons and Learnings from 100 Resilient Cities and Cape Town », Sustainability, 12(2), p.550, 2020 .

[CUT 08] CUTTER S. L., BARNES L., BERRY M., BURTON C., EVANS E., TATE E., WEBB J., « A place-based model for understanding community resilience to natural disasters ", Global environmental change, 18(4), p. 598-606, 2008 .

[CUT 16] CUTTER S.L., " Resilience to What? Resilience for Whom? ", The Geographical Journal, 182(2), p.110-113, 2016.

[DAV 14] DAVOUDI S., « Climate change, securitization of nature, and resilient urbanism », Environment 1002.1002 and Planning C: Government and Policy, 32(2), p.360-375, 2014.

[DES 13] DESOUZA K.C., FLANERY T.H., « Designing, planning, and managing resilient cities: A conceptual framework », Cities, n³5, p.89-99, 2013.

[DJA 05] DJAMENT-TRAN G., La reproduction de la centralité romaine de la «Ville Éternelle » à la capitale de l'Italie. Essai de géohistoire urbaine, Thèse de doctorat, Université Paris-Diderot-Paris VII, 2005.

[DJA 12] DJAMENT-TRAN G., REGHEZZA M. (eds.), Résiliences urbaines : les villes face aux catastrophes, Éditions Le Manuscrit, Paris, 2012. 
[DOR 20] DORNELLES A.Z., BOYD E., NUNES R.J., ASQUITH M., BOONSTRA W.J., DELABRE I., DENNEY J.M., GRIMM V., JENTSCH A., NICHOLAS K.A., SCHRÖTER M., SEPPELT R., SETTELE J., SHACKELFORD N., STANDISH R.J, YENGOH G.T, OLIVER T.H., « Towards a bridging concept for undesirable resilience in socioecological systems », Global Sustainability, n³, 2020.

[ELM 14] ELMQVIST T., «Urban resilience thinking », Solutions, 5(5), p.26-30, 2019.

[FAI 18] FAINSTEIN S.S., « Resilience and Justice: Planning for New York City», Urban Geography, 39(8), 2018.

[FAS 19] FASTENRATH S., COENEN L., DAVIDSON K., « Urban resilience in action: The Resilient Melbourne Strategy as transformative urban innovation policy?», Sustainability, 11(3), p.693, 2019.

[FIS 16] FISICHELLI N.A., SCHUURMAN G.W., «Is Resilience "Maladaptive"? Towards an Accurate Lexicon for Climate Change Adaptation », Environmental Management, 57(4), p.753-758, 2016.

[FIT 19] FITZGIBBONS J., MITCHELL C.L., « Just urban futures? Exploring equity in "100 Resilient Cities », World Development, ${ }^{\circ} 122$, P.648-659, 2019.

[FOL 06] FOLKE C., «Resilience: The emergence of a perspective for social-ecological systems analyses », Global Environmental Change, 16(3), 253-267, 2006.

[FRA 18] FRANCIS T.R., WILKINSON S., MANNAKKARA S., CHANG-RICHARDS A., « Post-disaster reconstruction in Christchurch: a "build back better" perspective », International Journal of Disaster Resilience in the Built Environment, 9(3), p.239-248, 2018.

[GOL 03] GOLDSHAK D.R., «Urban Hazard Mitigation: Creating Resilient Cities », Natural Hazard Review, 4(3), 2003.

[HER 10] HERNANDEZ J., ReNew Orleans? Résilience urbaine, mobilisation civique et création d'un "capital de reconstruction" à la Nouvelle-Orléans après Katrina, Thèse de doctorat, Université Paris X-Nanterre, 2010.

[JON 20] JON I., REGHEZZA-ZITT M., " Late modernity to postmodern? The rise of global resilience and its progressive potentials for local disaster planning (Seattle and Paris) », Planning Theory \& practice, 21(1), p.94-122, 2020.

[LEB 06] LE BLANC A., Les politiques de conservation du patrimoine urbain comme outils de gestion du risque sismique, Trois exemples en Italie : Noto, Assise, Gémone, Thèse de doctorat, 2006.

[LEF 91] LEFEBVRE H., The Production of Space [La production de l'espace 1974], Malden, 1991.

[LEI 18] LEITNER H., SHEPPARD E., WEBBER S., COLVEN E., « Globalizing urban resilience », Urban Geography, 39(8), p.1276-1284, 2018.

[LHO 13] LHOMME S., SERRE D., DIAB Y, LAGANIER R., «Urban technical networks resilience assessment » in R. LAGANIER (Ed.), Resilience and urban risk management, p.109-117, CRC Press, London, 2013.

[LU 13] LU P., STEAD D., « Understanding the notion of resilience in spatial planning: A case study of Rotterdam, The Netherlands », Cities, n³5, p.200-212, 2013.

[MCG 16] McGREAVY B., « Resilience as discourse », Environmental Communication, 10(1), p.104-121, 2016.

[MEE 15] MEEROW S., NEWELL, J.P., «Resilience and complexity: A bibliometric review and prospects for industrial ecology », Journal of Industrial Ecology, 19(2), p.236-251, 2015.

[MEE 19] MEEROW S., NEWELL J.P., «Urban resilience for whom, what, when, where, and why? », Urban Geography, 40(3), p.309-329, 2019.

[MEE 16] MEEROW S., NEWELL J.P., SULTS M., « Defining urban resilience: A review », Landscape and Urban Planning, n¹47, p. 38-49, 2016.

[MEE 19] MEEROW S., PAJOUHESH P., MILLER T.R., « Social equity in urban resilience planning », Local Environment, 24(9 , p.793-808, 2019.

[MOS 19] MOSER S, MEEROW S., ARNOTT J., JACK-SCOTT E., « The turbulent world of resilience: interpretations and themes for transdisciplinary dialogue », Climatic Change, 153(1), p.21-40, 2019.

[NOI 13] NOISET H., MIRLOU L., ROBERT S., « La résilience des formes. La ceinture de Paris sur la rive droite », Études Rurales, n¹91, p.191-219, 2013.

[PAH 07] PAHL-WOSTL C., « Transitions towards adaptive management of water facing climate and global change. », Water Resource Management, 21(1), p. 49-62, 2007. 
[PEL 03] PELLING M., The vulnerability of cities: social resilience and natural disaster, Earthscan, London, UK, 2003.

[PEL 13] PELLING, M., BLACKBURN S. (eds), Megacities and the coast: risk, resilience and transformation, Routledge, New York, New York, USA, 2013.

[PEL 15] PELLING M., O’BRIEN K., MATYAS D, « Adaptation and transformation», Climatic Change, 33(1), p. 113$127,2015$.

[REG 15] REGHEZZA-ZITT M., RUFAT S., Resilience Imperative: Uncertainty, Risk and Disasters, Elsevier, 2015.

[REG 19] REGHEZZA-ZITT M., RUFAT S., « Disentangling the Range of Responses to Threats, Hazards and Disasters. Vulnerability, Resilience and Adaptation in question », Cybergeo, 2019.

[ROB 20] ROBERT S., La résilience : un cadre pour penser la persistance et le changement dans les formes du paysage, Habilitation à diriger des recherches, Université Paris 1 - Panthéon Sorbonne, 2020.

[ROB 20] ROBERTS D., DOUWES J., SUTHERLAND C., SIM V., « Durban's 100 Resilient Cities journey: governing resilience from within », Environment and Urbanization, 32(2), p.547-568, 2020.

[RUF 15] RUFAT S., «Critique de la résilience pure », in M. REGHEZZA and S. RUFAT (eds.), Résiliences. Sociétés et territoires face à l'incertitude, aux risques et aux catastrophes, Iste Éditions, London, p.187-210, 2015.

[SPA 17] SPAANS M., WATERHOUT, « Building up resilience in cities worldwide - Rotterdam as participant in the 100 Resilient Cities Program », Cities, n61, p. 109-116, 2017.

[SLO 00] SLOVIC P. (ed.), The Perception of Risk, London, UK: Earthscan, 2000.

[SOL 17] SOLECKI W., PELLING M., GARSCHAGEN M., «Transitions between risk management regimes in cities», Ecology and Society, 22(2), 2017.

[THE 21] THERRIEN M.C., NORMANDIN J.M., PATERSON S., PELLING M., « Mapping and weaving for urban resilience implementation: A tale of two cities », Cities, n ${ }^{\circ}$ 108, 102931, 2021.

[TOU 12] TOUBIN M., LHOMME S., DIAB Y., SERRE D., LAGANIER R., « La résilience urbaine : Un nouveau concept opérationnel vecteur de durabilité urbaine? », Développement durable et territoires. Économie, géographie, politique, droit, sociologie, 3(1), 2012.

[VAL 14] VALE L.J., " The politics of resilient cities: whose resilience and whose city? », Building Research \& Information, 42(2), p.191-201, 2014.

[VAL 05] VALE L.J., CAMPANELla T.J., The Resilient City: How Modern Cities, Oxford University Press, Oxford, 2005.

[WEI 15] WEICHSELGARTNER J., KELMAN I., « Geographies of resilience: Challenges and opportunities of a descriptive concept », Progress in Human Geography, 39(3), p.249-267, 2015.

[WIN 14] WINDERL T., « Disaster resilience measurements: Stocktaking of ongoing efforts in developing systems for measuring resilience », UNDP, http://www.preventionweb.net/files/37916 disasterresiliencemeasurementsundpt.pdf, 2014. 